AGRICA: Journal of Sustainable Dryland Agriculture, 14 (2): 152-157 (2021)

ISSN-Online: 2715-4955; ISSN-Cetak: 2715-6613

DOI: https://doi.org/10.37478/agr.v14i2.1482

\title{
UJI KADAR CEMARAN KADMIUM DARI DALAM TANAH SAWAH DAN BERAS DI KELURAHAN LAPE KECAMATAN AESESA KABUPATEN NAGEKEO
}

\author{
Emilia Simplisiu Ake Wangge, Edeltrudis Sito, Charly Mutiara \\ Program studi Agroteknologi, Fakultas Pertanian Universitas Flores \\ Jln. Sam Ratulanggi XX Paupire, Ende, Nusa Tenggara Timur \\ simplisiawangge@gmail.com
}

\begin{abstract}
Test Of Cadmium Pollution From Inside Rice And Rice Soil In Lape Sub-District, Aesesa District, Nagekeo Regency. Cadmium is one of the heavy metals that is harmful to human health and is widely found in agricultural land with the use of phosphorus-based fertilizers such as in rice fields. The research was conducted in Lape Village, Aesesa District, which produces Inpari and Ciherang varieties of rice. Rice samples were taken directly from the farmers who cultivate the two types of plants. Analysis of cadmium from rice samples using the Atomic Absorption Spectrophotometry (AAS) method and comparing it with the maximum limit of heavy metal contamination in rice set by the Indonesian National Standard (SNI) 6989.16:2009 . The results showed that the cadmium content in rice was $<0.001 \mathrm{ppm}-0.001 \mathrm{ppm}$. The content of cadmium in the rice is still below the set standard, this is closely related to soil conditions such as soil $\mathrm{pH}, \mathrm{C}$-organic at the study site, where high organic matter conditions affect low cadmium content.
\end{abstract}

Keywords: Contaminant, fertilizers, heavy metal, phosphorus.

\section{PENDAHULUAN}

Beras merupakan makanan pokok utama sebagian besar masyarakat Indonesia Komposisi beras per 100 gram bahan adalah energy $360 \mathrm{kkal}$, protein 6,6gr, lemak 0,58 gr,dan karbohidrat 79,34 gr (Winarsih et al., 2017). Komposisi beras berbeda-beda diantara varietas-varietasnya tergantung aktivitas budidaya. Karena itu, aktivitas budidaya tanaman perlu diperhatikan untuk memperoleh beras dengan kualitas yang baik (Hernawan \& Meylani, 2016).

Kualitas beras yang baik dapat dihasilkan melalui pengeloaan tanaman yang baik. Hasil wawancara kepada petani di kelurahan Lape, Kecamatan Aesesa Kabupaten Nagekeo, sebagian besar para petani membudidaya tanaman padi varietas Inpari dan Ciherang. Pupuk yang digunakan adalah Urea $200-300 \mathrm{~kg} / \mathrm{ha}$, TSP 50-100 kg/ha dan SP36 100-200 kg/ha serta pupuk kandang.Penggunaan pupuk kandang akan meningkatkankandungan bahan organik dalam tanah. Sedangkan penggunaan pupuk anorganik fosforyang berlebihan dapat meningkatkan kandungan Kadmium di dalam tanah (Simanjuntak et al., 2015). 
Wangge: Uji kadar cemaran kadmium dari dalam tanah sawah dan beras

Penyebab kualitas tanah yang semakin menurun bukan hanya karena pupuk anorganik, tetapi juga penggunaannya dengan intensif. Hasil penelitian Roidah (2013), menyatakan penggunaan pupuk yang berlebihan menghasilkan limbah di daerah pertanian, khususnya cairan berlumpur. Limbah tersebut terus-menerus terendapkan di lahan pertanian dalam jangka panjang dapat menurunkan produktivitas hasil panen dan menurunkan kualitas produk pertanian.

Kandungan kadmium secara umum pada tanah bebas polusi yaitu $0.06 \mathrm{ppm}$ (Setyoningrum et al., 2014). Sumber kadmium di dalam tanah berasal dari pelapukan bahan mineral tanah endapan, udara, aktivitas volkanik, emisi dari industri peleburan, dan pembakaran batu bara. Kadmium dalam tanah akan meningkat bila terjadi aktivitas manusia (Wardhani et al., 2016). Aktivitas manusia yang dapat meningkatkan kandungan kadmium seperti pemberian pupuk anorganik yang mengandung fosfat. Kandungan kadmium di dalam pupuk fosfat adalah sebesar 0,1-170 ppm (Bolly, 2012).

Pemberian pupuk Fosfor yang terus menerus tidak hanya dapat meningkatkan kandungan kadmium di tanah, tapi juga tanaman padi yang tumbuh di tanah tersebut (Purbalisa et al., 2017). Kadmium bersifat mobile sehingga lebih mudah tersedia bagi tanaman (Istarani \& Pandebesie, 2014). Kadmium terdeteksi di semua bagian tanaman baik akar, jerami maupun berasdan akumulasi terbesar ada pada jaringan akar (Krisnawati, 2013).

Dampak dari kadmium pada bahanbahan makanan akan menimbulkan berbagai penyakit kronis, diantaranya ginjal dan kerusakan tulang (Pratiwi, 2020). Menurut laporan Nogawa dan Suwazono, (2011) dalam Istarani \& Pandebesie (2014) diketahui bahwa banyak warga Jepang yang meninggal karena kerusakan tulang akibat mengkonsumsi air dan beras yang telah tercemar kadmium. Karena itu, penelitian dengan tujuan untuk menguji cemaran logam berat kadmium pada beras yang dihasilkan petani padi sawah di Kelurahan Lape Kecamatan Aesesa Kabupaten Nagekeo.

\section{BAHAN DAN METODE}

Pengambilan sampel tanah dilakukan pada sawah-sawah di Kelurahan Lape Kabupaten Nagekeo.Waktu pelaksanaan penelitian ini yaitu pada bulan Juli 2020 sampai dengan bulan November 2020.Alat yang digunakan adalah $\mathrm{pH}$ meter, cangkul, bor tanah dan alat tulis menulis. Sedangkan bahan yang digunakan adalah tanah dan beras.

Variabel yang diamati adalah kadmium di dalam beras dan tanah serta $\mathrm{pH}$ dan $\mathrm{C}$ Organik tanah. Analisis kadmium 
menggunakan metode Spektofotometri Serapan Atom (SSA), $\mathrm{pH}$ menggunakan $\mathrm{pH}$ meter dan C-Organik menggunakan metode walkey \& Black.

\section{Analisis Data}

Setiap variabel pengamatan dianalisis secara kimia di laboratorium. Hasil analisis kimia tersebut lalu dibandingkan dengan batas minimum cemaran kadmium pada pangan (Standar Nasional Indonesia 7387:2009) dan kriteria kimia tanah dari pusat penelitian tanah bogor. Hasil analisis sifat kimia tanah juga diregresikan untuk melihat pengaruhnya.Hasil perbandingan dan regresi tersebut kemudian dideskripsikan.

\section{HASIL DAN PEMBAHASAN}

Kadmium pada beras dan tanah serta kandungan C-Organik dan $\mathrm{pH}$ tanah telah dianalisis. Hasil analisisnya dapat dilihat pada Tabel 1.

Tabel 1. Hasil Analisis Sifat Kimia Tanah Di DalamTanahdan Beras

\begin{tabular}{|c|c|c|c|}
\hline $\mathrm{NO}$ & Variabel Pengamatan & Metode Analisis & Hasil Analisis \\
\hline \multirow[t]{2}{*}{1.} & Kadmium tanah Inpari & Spektro $\quad$ Photometry & 0,003 ppm \\
\hline & & Serapan Atom & \\
\hline \multirow[t]{2}{*}{2.} & Kadmium tanah & Photometry & \\
\hline & Ciherang & Serapan Atom & $<0,001$ ppm \\
\hline \multirow[t]{2}{*}{3.} & Kadmium beras Inpari & Photometry & $0,001 \mathrm{ppm}$ \\
\hline & & Serapan Atom & \\
\hline \multirow[t]{2}{*}{4.} & Kadmium beras & SpektroPhotometry & $<0,001 \mathrm{ppm}$ \\
\hline & Ciherang & Serapan Atom & \\
\hline 5. & C-Organik tanah Inpari & Walkey \& Black & $4,24 \%$ \\
\hline 6. & $\begin{array}{l}\text { C-Organik tanah } \\
\text { Ciherang }\end{array}$ & Walkey \& Black & $3,49 \%$ \\
\hline 7. & $\mathrm{pH}$ tanah Inpari & $\mathrm{pH}$ Meter & 5 \\
\hline 8. & $\mathrm{pH}$ tanah Ciherang & $\mathrm{pH}$ Meter & 4,5 \\
\hline
\end{tabular}

\section{Kadmium Pada Tanah}

Berdasarkan hasil analisis kandungan kadmium pada tanah sawah di kelurahan Lape berkisar antara < 0,001 ppm sampai dengan 0,003 ppm. Sedangkan standar kandungan kadmium yang ada di dalam tanah menurut Ministri or state for population environment republic of Indonesian anddol house University Canada sebesar 0,5 ppm (Komarudin et al.,
2021). Kandungan kadmium yang terdapat di Kelurahan Lape sangat rendah. Hal ini dapat terjadi karena selain para petani padi sawah dan berbagai sayuran menggunakan pupuk anorganik seperti Urea dan TSP, juga menggunakan pupuk kandang.

Berbagai faktor dapat mempengaruhi kandungan kadmium di dalam tanah diantranya adalah bahan organik. Berdasarkan hasil analisis kandungan C- 
organik tanah di kelurahan Lape berkisar antara 3,49\% sampai dengan $4,24 \%$ dengan kriteria tinggi. Keadaan ini disebabkan oleh adanya pemberian kotoran ternak yang menjadi penyumbang bagi bahan organik tanah. Kondisi tersebut menyebabkan kandungan kadmium menjadi rendah.Bahan organik akan berikatan dengan logam berat membentuk kelasi/kelat. Kelasi bahan organik dapat mengatur ketersediaan logam di dalam tanah (Sutrisno \& Kuntyastuti, 2015).

Pengaruh kadar bahan organik yang besar terhadap kadmium di dalam tanahpun terlihat dari hasil analisis regresi yang menunjukkan nilai $\mathrm{R}$ square sebesar 1 . Hal ini menunjukkan pengaruh C-Organik terhadap kandungan kadmium sangat tinggi.

Berdasarkan hasil analisis $\mathrm{pH}$ tanah yang dilakukan di Kelurahan Lape Kecamatan Aesesa berada pada kisaran antara 4,5 sampai dengan 5,0 yang tergolong dalam kategori masam. Pada kondisi tanah dengan $\mathrm{pH}$ rendah, unsur kadmium akan larut dalam air tanah sehingga lebih mudah tercuci ke lapisan bawah tanah apabila turun hujan atau akan ikut terserap oleh akar tanaman pada proses penyerapan nutrient. Pada kondisi tanah dengan $\mathrm{pH}$ tinggi, kadmium akan terikat oleh koloid tanah dan bahan organik atau diendapkan dalam bentuk hidroksida, sehingga terhindar dari proses pencucian dan penyerapan oleh akar tanaman (Nur, 2013; Rahmawati, 2011).

Hasil analisis regresi yang dilakukanmenunjukkan bahwa pengaruh pH tanah terhadap kandungan kadmium di dalam tanah sangat tinggi. Hal ini ditunjukkan oleh nilai R Square sebesar 1 . Keberadaan $\mathrm{pH}$ tanah sangat mempengaruhi kelarutan kadmium di dalam larutan tanah.

\section{Kadmium Pada Beras}

Hasil analisis kandungan kadmium pada beras berkisar antara $<0,001$ ppm sampai dengan 0,001 ppm. Kandungan kadmium ini masih lebih rendah dari batas kritis kadmium di dalam beras yang telah ditetapkan. Batas kritis kadmium di beras adalah 0,4 ppm (SNI .7387. 2009). Kandungan kadmium beras yang terdapat di Kelurahan Lape sangat rendah sehingga aman untuk dikonsumsi.

Kandungan kadmium pada beras dipengaruhi oleh kandungan kadmium di dalam tanah dan kondisi tanah diantaranya $\mathrm{pH}$ tanah dan kandungan $\mathrm{C}$ organik (Mohamad, 2013). Hal ini dikarenakan kadmium akan terikat oleh koloid tanah dan bahan organik atau diendapkan dalam bentuk hidroksida, sehingga terhindar dari penyerapan oleh akar tanaman (Bolly, 2012). 


\section{SIMPULAN}

Kandungan kadmium di dalam beras inpari yaitu 0,001 ppm dan beras Ciherang $<0,001$ ppm sampai dengan 0,001 ppm.

\section{UCAPAN TERIMAKASIH}

Penelitian ini dapat dilaksanakan karena adanya beberapa pihak yang mendukung kami, untuk itu perkenankanlah kami menyampaikan ucapan terimakasih kepada Pimpinan Fakultas Pertanian dan Program Studi yang telah memberikan masukan, kritik dan saran kepada penulis serta semua pihak yang telah membantu penelitian dan penyelesaian penulisan artikel ini.

\section{DAFTAR PUSTAKA}

Bolly, Y. Y. (2012). Kandungan Fosfor Dan Kadmium Pada Tanah Dan Beras Serta Risiko Kadmium Bagi Kesehatan Penduduk Di Kelurahan Tarus. Agrica, 5(2), 115-130. https://doi.org/10.37478/agr.v5i2.452

Hernawan, E., \& Meylani, V. (2016). Analisis Karakteristik Fisikokimia Beras Putih, Beras Merah, Dan Beras Hitam (Oryza sativa L., Oryza nivara dan Oryza sativa L. indica). Jurnal Kesehatan Bakti Tunas Husada: Jurnal Ilmu-Ilmu Keperawatan, Analis Kesehatan Dan Farmasi, 15(1), 79. https://doi.org/10.36465/jkbth.v15i1.1 54

Istarani, F., \& Pandebesie, E. S. (2014). Studi Dampak Arsen (As) dan Kadmium (Cd) terhadap Penurunan Kualitas Lingkungan. Jurnal Teknik
Pomits, $\quad 3(1)$, 1-6. https://doi.org/10.12962/j23373539.v3 i1.5684

Komarudin, D., Hidayat, F., \& Putri, D. K. (2021). Analisis Kadar Cemaran Logam Berat Timbal ( $\mathrm{Pb}$ ) dan Kadmium ( Cd ) Pada Air Tanah Di Perumahan Perumnas Bekasi. IonTech, 02(01), 8-13. http://iontech.ista.ac.id/index.php/iont ech/article/view/32/13

Krisnawati, A. (2013). Pencemaran Kadmium Dan Prospek Pemuliaan Tanaman Kedelai Berkandungan Kadmium Rendah. Buletin Palawija, 26, 61-71. https://media.neliti.com/media/publica tions/225833-pencemaran-kadmiumdan-prospek-pemuliaan-44d6601c.pdf

Mohamad, E. (2013). Pengaruh Variasi Waktu Kontak Tanaman Bayam Duri Terhadap Adsorpsi Logam Berat Kadmium (Cd). Jurnal Entropi, 8(1), 562-571.

https://ejurnal.ung.ac.id/index.php/JE/ article/view/1165

Nur, F. (2013). Fitoremediasi Logam Berat Kadmium ( Cd ). Biogenesis, 1(1), 7483.

https://publikasiilmiah.ums.ac.id/xmlu i/bitstream/handle/11617/3438/1.

ATIK

RAHMAWATI.pdf? sequence $=1 \&$ is Al lowed=y

Pratiwi, D. Y. (2020). Dampak Pencemaran Logam Berat (Timbal, Tembaga, Merkuri, Kadmium, Krom) terhadap Organisme Perairan dan Kesehatan Manusia. Jurnal Akuatek, 1(1), 59-65. http://journal.unpad.ac.id/akuatek/artic le/viewFile/28135/13485 
Wangge: Uji kadar cemaran kadmium dari dalam tanah sawah dan beras

Purbalisa, W., Mulyadi, M., \& Purnariyanto, F. (2017). Kadar Kadmium dan Hasil Produksi Padi Pada Tanah Tercemar Kadmium Yang Telah Diremediasi. Seminar Nasional Pendidikan Biologi Dan Saintek II, 169-179.

https://publikasiilmiah.ums.ac.id/xmlu i/handle/11617/9326

Rahmawati, A. (2011). Pengaruh Derajad Keasaman Terhadap Adsorpsi Logam Kadmium(II) Dan Timbal(II) Pada Asam Humat. Jurnal Penelitian Sains \& Teknologi, 12(1), 1-14. https://publikasiilmiah.ums.ac.id/xmlu i/bitstream/handle/11617/3438/1.

ATIK

RAHMAWATI.pdf? sequence $=1 \&$ is Al lowed $=\mathrm{y}$

Roidah, I. S. (2013). Manfaat Penggunaan Pupuk Organik Untuk Kesuburan Tanah. Universitas Tulungagung BONOROWO, 1(1), 30-42. https://doi.org/https://doi.org/10.36563 /bonorowo.v1i1.5

Setyoningrum, H. M., Hadisusanto, S., Budaya, J. L., Utara, S., Selatan, J. T., Utara, S., Telp, Y., Utara, S., Kaliurang, J., \& Telp, Y. (2014). Kandungan Kadmium (Cd) Pada Tanah Dan Cacing Tanah Di Tpas Piyungan, Bantul, Daerah Istimewa Yogyakarta (Cadmium (Cd) Content in Soil and Earthworms in Piyungan Controlled Landfill Municipal Waste Disposal, Bantul Yogyakarta Special District). Jurnal Manusia Dan Lingkungan, 21(2), 149-155. https://doi.org/10.22146/jml.18538

Simanjuntak, J., Hanum, H., \& Rauf, A. (2015). Ketersediaan Hara Fosfor dan Logam Berat Kadmium Pada Tanah Ultisol Akibat Pemberian Fosfat Alam dan Pupuk Kandang Kambing Serta Pengaruhnya Terhadap Pertumbuhan dan Produksi Tanaman Jagung (Zea mays L.). Online Agroteknologi, 3(2337), 5-24. https://media.neliti.com/media/publica tions/103876-ID-ketersediaan-harafosfor-dan-logam-berat.pdf

Sutrisno, \& Kuntyastuti, H. (2015). Pengelolaan Cemaran Kadmium Pada Lahan Pertanian Di Indonesia. Buletin Palawija, 13(1), 83-91. https://doi.org/10.21082/bulpa.v13n1. 2015.p83-91

Wardhani, E., Roosmini, D., \& Notodarmojo, S. (2016). Pencemaran Kadmium Di Sedimen Waduk Saguling Provinsi Jawa Barat. Jurnal Manusia Dan Lingkungan, 23(3), 285-294.

http://eprints.itenas.ac.id/1773/1/Pence maran Kadmium di Sedimen Waduk Saguling \%28Jurnal\%29.pdf

Winarsih, A., Respatijarti, \& Damanhuri. (2017). Karakterisasi Beberapa Genotip Padi (Oryza sativa L.) Berkadar Antosianin Tinggi. Produksi Tanaman, 5(7), 1070-1076. http://protan.studentjournal.ub.ac.id/in dex.php/protan/article/viewFile/479/4 82 